\title{
CTNNB1 mutation analysis is a useful tool for the diagnosis of desmoid tumors: a study of 260 desmoid tumors and 191 potential morphologic mimics
}

Sophie Le Guellec ${ }^{1}$, Isabelle Soubeyran ${ }^{2}$, Philippe Rochaix ${ }^{1}$, Thomas Filleron ${ }^{3}$, Agnès Neuville ${ }^{2,4}$, Isabelle Hostein ${ }^{2}$ and Jean-Michel Coindre ${ }^{2,4}$

${ }^{1}$ Biology-Pathology Medication Department, Institut Claudius Regaud, Toulouse, France; ${ }^{2}$ Department of Pathology and INSERM U916, Institut Bergonié, Bordeaux, France; ${ }^{3}$ Department of Biostatistics, Institut Claudius Regaud, Toulouse, France and ${ }^{4}$ Laboratory of Pathology, University Bordeaux Ségalen, Bordeaux, France

\begin{abstract}
Desmoid tumors are benign monoclonal fibroblastic or myofibroblastic neoplasms, characterized by local invasiveness and high rates of recurrence. Desmoid tumors must be distinguished from benign fibroblastic and myofibroblastic lesions, as well as from low-grade sarcoma, which can appear histologically similar to desmoid tumors. This differential diagnosis can be very difficult, especially when diagnosis is based on a core needle biopsy. On the molecular level, most sporadic desmoid tumors are associated with mutations of the $\beta$-catenin gene (CTNNB1). A minority of desmoid tumors are associated with Gardner syndrome and mutations of the familial adenomatous polyposis gene. We identified the common CTNNB1 mutations associated with sporadic desmoid tumors by direct sequencing: in (i) 260 cases of typical desmoid tumors; and (ii) in 191 cases of spindle cell lesions, which can morphologically 'mimic' desmoid tumors. Formalin-fixed paraffin-embedded tissues were obtained via core needle biopsy $(n=150)$ or open biopsy/surgical excision $(n=301)$. Only 16 cases $(4 \%)$ were not analyzable (Bouin's fixed tissue). CTNNB1 mutations were observed in 223 of 254 (88\%) of sporadic desmoid tumors. No CTNNB1 mutations were detected in all other lesions $(n=175)$ studied. CTNNB1 sequencing can be easily and reliably done using tissues obtained via core needle biopsy. Detection of CTNNB1 mutations in formalinfixed paraffin-embedded tissues among spindle cell lesions is proposed as a specific diagnostic tool for the diagnosis of desmoid tumors. This result has significant implications for patient care and management. Modern Pathology (2012) 25, 1551-1558; doi:10.1038/modpathol.2012.115; published online 6 July 2012
\end{abstract}

Keywords: CTNNB1 mutation; desmoid tumor; diagnostic tool; sequencing

Desmoid tumors are rare mesenchymal fibroblastic or myofibroblastic monoclonal neoplasms with an estimated incidence of two to four cases per million inhabitants per year. ${ }^{1}$ They arise primarily in the extremities and the trunk wall, followed by the abdominal wall and the abdominal cavity. ${ }^{2}$ Most cases develop sporadically in young adults, whereas a few cases occur with family backgrounds of adenomatous polyposis. ${ }^{3}$ Desmoid tumors are

Correspondence: Professor J-M Coindre, MD, Department of Pathology and INSERM U916, Institut Bergonié, Bordeaux 33076, France.

E-mail: j.coindre@bordeaux.unicancer.fr

Received 21 February 2012; revised 14 May 2012; accepted 31 May 2012; published online 6 July 2012 low-grade tumors that are generally highly invasive and locally aggressive, but do not metastasize., ${ }^{4,5}$ However, the clinical course of desmoid tumors is unpredictable and some spontaneous regression has been observed. As a result, a 'wait and see' approach has been recently proposed. ${ }^{6}$

Histological diagnosis of a desmoid tumor, based on open biopsy or surgical excision, is usually straight forward. However, the universal use of core needle biopsies makes this diagnosis much more difficult. Several spindle cell lesions, such as lowgrade sarcomas (particularly low-grade fibromyxoid sarcomas), or reactive lesions such as nodular fasciitis and scars, can appear similar to desmoid tumors. In the intra-abdominal cavity, desmoid tumors can quite often be mistaken for GIST. 
Tumorigenesis of sporadic desmoid tumors is linked to $\beta$-catenin stabilization involving $\beta$-catenin/WNT/TCF signaling. ${ }^{7,8}$ Several recent studies show that CTNNB1 mutations are highly prevalent and were detected in 84 to $87 \%$ of all sporadic desmoid tumors. However, immunohistochemical detection of nuclear $\beta$-catenin is not a reliable test for distinguishing desmoid tumors from benign or malignant fibroblastic lesions. ${ }^{9-13}$

In this study, we report the prevalence and spectra of CTNNB1 mutations in a large cohort of sporadic desmoid tumors compared with a panel of lesions known to be histologically similar to or 'mimic' desmoid tumors, in order to evaluate the potential role of CTNNB1 genotyping in the daily practice for positive and differential diagnosis of desmoid tumors.

\section{Materials and methods}

\section{Case and Sample Selection}

Ethical approval from the appropriate committees was obtained. Formalin-fixed, paraffin-embedded

Table 1 Description of the 191 spindle cell non-desmoid lesions

\begin{tabular}{lrr}
\hline Subgroups & $\begin{array}{c}\text { Samples } \\
\text { analyzed }\end{array}$ & $\begin{array}{c}\text { DNA } \\
\text { extracted }\end{array}$ \\
\hline Sarcoma & 12 & 11 \\
$\quad$ LGFMS & 8 & 8 \\
Low-grade sarcoma nos & 21 & 21 \\
GIST & 19 & 17 \\
Leiomyosarcoma & 14 & 11 \\
MPNST & 23 & 17 \\
Synovial sarcoma & & \\
Reactive processes & 34 & 34 \\
Scar & 16 & 15 \\
Fasciitis/myositis & & \\
Benign tumors & 16 & 16 \\
$\quad$ Fibroma & 2 & 1 \\
Superficial fibromatosis & 1 & 1 \\
Fibrothecoma & 1 & 1 \\
Perineurioma & 1 & 19 \\
Leiomyoma & 1 & 175 \\
Ossifying fibromyxoid tumor & 22 & \\
Sarcomatoid carcinoma & 191 & \\
Total number & & \\
\hline
\end{tabular}

Abbreviations: GIST, gastrointestinal stromal tumor; MPNST, malignant peripheral nerve sheath tumor; LGFMS, low-grade fibromyxoid sarcoma.

${ }^{a}$ DNA extracted: samples which presented sufficient DNA extracted for CTNNB1 exon 3 genotyping. specimens accrued between 2008 and 2011 were retrieved from Institut Bergonié's pathology archives (Bordeaux, France). All tissue samples were obtained via core needle biopsy, open biopsy or surgical excision.

The study cohort included 260 cases of desmoid tumors and 191 non-desmoid spindle cell lesions. For the cohort of desmoid tumors, the following clinical data were collected: gender, age diagnosis, location (intra-abdominal, abdominal wall and extraabdominal), size of tumor and cases of Gardner syndrome. The heterogeneous group of non-desmoid spindle cell lesions contained four main subgroups: sarcomas, benign fibroblastic tumors, reactive processes and sarcomatoid carcinomas (Table 1). The 12 cases of low-grade fibromyxoid sarcoma harbor the characteristic TLS (FUS) rearrangement (fluorescent in situ hybridization-FISH; data not shown). The 21 GIST present characteristic KIT mutations (exons 9, 11,13 or 17) or PDGFRA mutations (exons 12, 14 or 18) (denaturing high-performance liquid chromatography and sequencing; data not shown). The 23 synovial sarcomas have a specific SS18 (SYT) gene rearrangement (FISH; data not shown).

For the purpose of this study, all cases were evaluated by routine hematoxylin and eosin-stained sections. All specimens were further screened and analyzed for histological controls by a pathologist specialized in soft tissue tumors (JMC) and only those with confirmed tissues adequate for analytic purposes were included. Moreover, paraffin blocks were sampled using a core needle in order to select only areas of tumor for DNA extraction.

\section{CTNNB1 Sequencing}

Following lysis of the $35 \mu \mathrm{m}$ tumor slices, nucleic acids were obtained using Qiagen column separation according to the manufacturer's instructions (Qiagen, Hilden, Germany). Formalin-fixed paraffinembedded tissues $(422,95 \%)$ and Bouin's fixed tissues $(20,5 \%)$ were used for DNA extraction. From the 451 specimens (biopsies or resections), available DNA for sequencing was obtained in 435 cases (96\%). DNA lymphocytes from 96 anonymous individuals were used as non-mutated controls. CTNNB1 exon 3 was amplified using two primer couples (primer $\mathrm{n}^{\circ} 1$ and primer $\mathrm{n}^{\circ} 2$ ). Primer sequences are reported on Table 2. Briefly, approximately $50 \mathrm{ng}$ of DNA was amplified with the thermal cycling profile of $95{ }^{\circ} \mathrm{C}$ for $5 \mathrm{~min}$, then 40 cycles of $95{ }^{\circ} \mathrm{C}$ for $30 \mathrm{~s}, 62{ }^{\circ} \mathrm{C}$ for $45 \mathrm{~s}, 72{ }^{\circ} \mathrm{C}$ for $45 \mathrm{~s}$, with a

Table 2 Primer sequences

\begin{tabular}{|c|c|c|}
\hline CTNNB1 gene & Forward primer & Reverse primer \\
\hline Primer $n^{\circ} 1$ & $5^{\prime}$-TCCAATCTACTAATGCTAATACTGTTTCGTA- $3^{\prime}$ & $5^{\prime}$-AGGTATCCACATCCTCTTCCTCAG-3' \\
\hline Primer $n^{\circ} 2$ & 5'-AACAGTCTTACCTGGACTCTGGAATC-3' & 5'-CATTCTGACTTTCAGTAAGGCAATG-3' \\
\hline
\end{tabular}


final extension at $72{ }^{\circ} \mathrm{C}$ for $20 \mathrm{~min}$. PCR products were sequenced using the same primers as for the PCR reaction with an automated cycle sequencing for both strands using the Big-Dye DyeDeoxy terminator cycle sequencing kit (Applied Biosystems, Foster City, CA, USA). Sequencing reactions were carried out on the ABI Prism 310 Genetic Analyzer (Applied Biosystems). As a reference for the $\beta$-catenin gene, NM 00109822091 aligned on a sequence of chromosome 3 (NCBI 36) was used.

\section{Statistical Analysis}

Data are summarized by frequency and percentages for categorical variables and by median and range for continuous variables. Differences between groups were assessed using $\chi^{2}$ analyses or Fisher's exact test for qualitative variables, and the KruskalWallis for continuous variables. For all statistical tests, differences were considered significant at the $5 \%$ level. Statistical analyses were performed using the STATA 11.0 software.

\section{Results}

\section{Histopathology}

Specimens obtained by open biopsy and surgical excision had the characteristic histological features of desmoid tumors: ${ }^{2}$ poorly circumscribed monotonous proliferation of slender fibroblastic cells, long sweeping fascicles of bland, collagenous stroma, characteristic prominent vasculature and entrapped atrophic skeletal muscle fibers simulating giants cells at the periphery of the lesion. Specimens obtained by core needle biopsy presented morphological characteristics strongly suggestive of desmoid tumors but were often incomplete.

\section{High Feasibility of Sequencing CTNNB1 Mutations Using Formalin-Fixed Paraffin-Embedded Tissues and Core Needle Biopsies}

Initially 451 lesions were included. Paraffin-embedded tissue was obtained via core needle biopsy $(n=150 ; 33 \%)$ or open biopsy/surgical excision $(n=301,67 \%)$. A total of 431 specimens were fixed in formalin (95\%) and 20 specimens were fixed in Bouin (5\%). In all, 435 cases had sufficient DNA extracted for CTNNB1 exon 3 genotyping. All desmoid tumors were analyzable and only 16 cases $(4 \%)$ of spindle cell lesions were not analyzable (Bouin's fixed tissue); including 6 synovial sarcomas, 3 sarcomatoid carcinomas, 3 malignant peripheral nerve sheath tumors, 1 low-grade fibromyxoid sarcoma, 2 leiomyosarcomas and 1 fasciitis (Table 1). All of these specimens were obtained from surgical excision. As a result, for the cohort of 175 cases mimicking desmoid tumors, we had to recruit retrospective cases to complete the
Table 3 Characteristics of patients with a desmoid tumor according to the CTNNB1 status

\begin{tabular}{|c|c|c|c|c|}
\hline $\begin{array}{l}\text { CTNNB1 } \\
\text { characteristics }\end{array}$ & Total (\%) & $\begin{array}{l}\text { Wild } \\
\text { CTNNB1 } \\
\text { (exon 3) } \\
(\%)\end{array}$ & $\begin{array}{l}\text { Mutated } \\
\text { CTNNB1 } \\
\text { (exon 3) } \\
(\%)\end{array}$ & $\mathrm{P}$-value* \\
\hline$N$ & 254 & $31(12)$ & $223(88)$ & \\
\hline $\begin{array}{l}\text { Age } \\
\text { Median, years } \\
\text { Range }\end{array}$ & $\begin{array}{c}41 \\
1-88\end{array}$ & $\begin{array}{c}39 \\
8-85\end{array}$ & $\begin{array}{c}42 \\
1-88\end{array}$ & 0.3483 \\
\hline $\begin{array}{l}\text { Sex } \\
\quad \text { Male } \\
\text { Female }\end{array}$ & $\begin{array}{c}76(30) \\
178(70)\end{array}$ & $\begin{array}{c}9(12) \\
22(12)\end{array}$ & $\begin{array}{c}67(88) \\
156(88)\end{array}$ & 0.9082 \\
\hline $\begin{array}{l}\text { Tumor site } \\
\text { Abdominal } \\
\text { cavity } \\
\text { Abdominal wall } \\
\text { Extra-abdominal } \\
\text { Unknown }\end{array}$ & $\begin{array}{c}59(24) \\
60(24) \\
129(52) \\
6\end{array}$ & $\begin{array}{c}5(8) \\
9(15) \\
17(13) \\
0\end{array}$ & $\begin{array}{c}54(92) \\
51(85) \\
112(87) \\
6\end{array}$ & 0.5296 \\
\hline $\begin{array}{l}\text { Tumor size } \\
\text { Median (mm) } \\
\text { Range } \\
\text { Unknown }\end{array}$ & $\begin{array}{c}45 \\
5-260 \\
111\end{array}$ & $\begin{array}{c}30 \\
12-200 \\
14\end{array}$ & $\begin{array}{c}46 \\
5-260 \\
97\end{array}$ & 0.2311 \\
\hline $\begin{array}{l}\text { Specimens } \\
\text { Core needle } \\
\text { biopsy } \\
\text { Open biopsy or }\end{array}$ & $\begin{array}{c}65(26) \\
189(74)\end{array}$ & $\begin{array}{l}10(15) \\
21(11)\end{array}$ & $\begin{array}{l}55(85) \\
168(89)\end{array}$ & 0.3639 \\
\hline
\end{tabular}

${ }^{*} P$-value: differences were considered statistically significant when $P<0.05$.

series. On the other hand, all cases recruited in daily practice contained high-quality analyzable DNA.

\section{High Frequency of CTNNB1 Mutations in Formalin- Fixed Paraffin-Embedded Tissues Specimens of Sporadic Desmoid Tumors}

After excluding cases with a family history of familial adenomatous polyposis or Gardner syndrome ( $n=6$, none with CTNNB1 mutations), a collection of 254 sporadic desmoid tumors remained and was included in this analysis (Table 3). Of these, 178 were female $(70 \%)$ and 76 were male $(30 \%)$. Median age was 41 years and ranged from 1 to 88 years. The following locations were involved: 129 in extra-abdominal locations (52\%), 59 in the abdominal cavity (24\%), 60 in the abdominal wall $(24 \%)$ and 6 of unknown site. The extra-abdominal desmoid tumors occurred: 59 in the limb (46\%), 53 in trunk wall (41\%) and 17 in the head and neck $(13 \%)$. The size was known in 143 cases and ranged from 5 to $260 \mathrm{~mm}$ (median, $45 \mathrm{~mm}$ ). A total of 65 specimens were obtained via core needle biopsy $(26 \%)$ and 189 via open biopsy or surgical excision $(74 \%)$. A mutation in exon 3 of the CTNNB1 gene was identified in $223(88 \%)$ of the 254 cases. The CTNNB1 mutation spectra mostly included three point mutations in two codons (41 and 45) (Figure 1). 
a

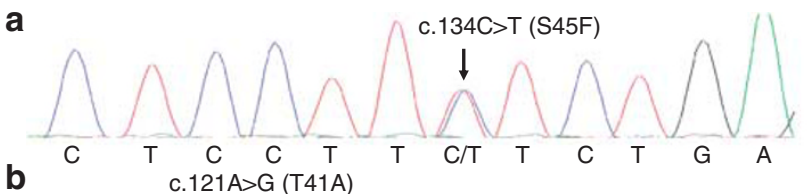

b

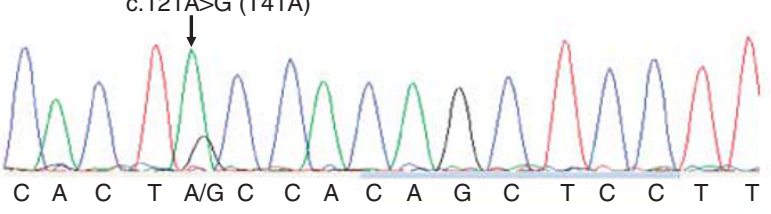

c

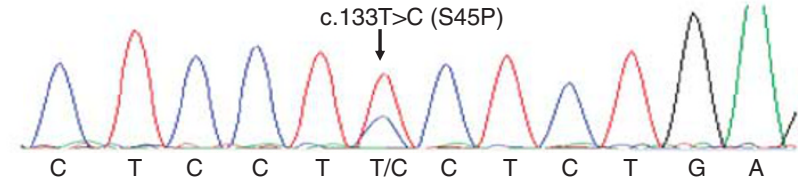

Figure 1 CTNNB1 mutations detected in fibromatosis tumors. Typical heterozygous missense mutations found in exon 3 CTNNB1 gene; (a) at codon $45(\mathrm{~S} 45 \mathrm{~F}),(\mathbf{b})$ at codon $41(\mathrm{~T} 41 \mathrm{~A})$ and (c) at codon $45(\mathrm{~S} 45 \mathrm{P})$.

\section{Characteristics of Patients with Sporadic Desmoid Tumors by CTNNB1 Genotype}

A mutation in exon 3 of the CTNNB1 gene was identified in $223(88 \%)$ of the 254 cases. No mutations were detected in the DNA extracted from the lymphocytes of the 96 controls. All of the sequences were controlled in an independent experiment. The CTNNB1 mutation spectra concerned mainly three point mutations in two codons (41 and 45): ACC to GCC in codon 41 (41A), resulting in the replacement of threonine by alanine, was identified in 132 cases (59\%); TCC to TTT in codon $45(45 \mathrm{~F})$, resulting in the replacement of serine by phenylalanine, was identified in 49 samples $(22 \%)$; and TCT to CCT in codon 45 (45P), resulting in the replacement of serine by proline, was identified in 27 samples $(12 \%)$. Further, in nine cases $(4 \%)$, we also detected a small in-frame deletion (Table 4). In six cases (3\%), other point mutations in exon 3 of the CTNNB1 gene were found:

- in codon 41 (41I), the replacement of threonine by isoleucine was identified in three samples.

- in codon 34 (34A), the replacement of glycine by arginine was identified in one sample (and detection of a change of nucleotide in intron 3 of CTNNB1 gene (c. $241+2 \mathrm{~T}>\mathrm{A}$ ), involving the site of splicing).

- in codon 37 (37A), the replacement of serine by phenylalanine was identified in one sample.

- one sample presented two point mutations in exon 3 CTNNB1: one in codon 33 (33T) resulting in the replacement of serine by threonine and one in codon $34(34 \mathrm{~A})$ resulting in the replacement of glycine by arginine.

None of the 175 lesions mimicking desmoid tumors analyzed harbored any CTNNB1 mutations.
No correlations were found between the presence of CTNNB1 gene mutations and the following variables: age at diagnosis, sex, tumor site, tumor size and type of specimens (Table 3 ). When analyzing the incidence of the specific CTNNB1 gene mutations, tumors in extra-abdominal sites had a higher incidence of the $45 \mathrm{~F}$ mutation $(P=0.0023)$. Furthermore, among extra-abdominal sites, tumors in the extremities had a higher incidence of the $45 \mathrm{~F}$ mutation $(P=0.005)$. No other associations were noted (Table 4).

\section{Discussion}

Our study confirms previous findings that CTNNB1 mutations are highly prevalent in sporadic desmoid tumors $^{9,14,15}$ and that desmoid CTNNB1 mutational spectra are very restricted..$^{9,16,17}$ Only three specific mutations are reported: two involving codon 45 (p.Ser45Pro and p.Ser45Phe) and one involving codon 41 (p.Thr41Ala). This study is the first to our knowledge to report the presence of other point mutations of exon 3 of CTNNB1 in desmoid tumors. These new point mutations are located in codon 41 (resulting in the replacement of threonine by isoleucine), in codon 34 (resulting in the replacement of glycine by arginine), in codon 37 (resulting in the replacement of serine by phenylalanine) and in codon 33 (resulting in the replacement of serine by threonine). The exon 3 CTNNB1 point mutations have already been described, but only in rare epithelial neoplasms and with a very low frequency. ${ }^{18-25}$ Indeed, $\beta$-catenin mutations are not exclusive to desmoid tumors and are also reported for several epithelial neoplasms at various prevalence levels. Table 5 quotes the main studies ${ }^{18-25}$ searching for exon 3 CTNNB1 mutations in different carcinoma (thyroid, ovary, uterine, prostate, colorectal, hepatoblastoma and hepatocarcinoma) with prevalence and type of mutations. The observed mutations are identical to the desmoid tumor mutations in $6 \%$ of all carcinomas studied and reported, which represents $28 \%$ of the exon 3 CTNNB1 mutations. However, from a morphological point of view, making the difference histologically between such neoplasms and desmoid tumors does not cause diagnostic problems.

The main focus of this study was to concentrate on the differential diagnosis of desmoid tumors from low-grade sarcomas, myofibroblastic benign lesions and reactive processes. The existence of CTNNB1 mutations in spindle cell lesions, which morphologically imitate desmoid tumors would detract from the value of detecting these mutations for a diagnostic purpose. To the best of our knowledge, this is the first study on exon 3 CTNNB1 mutations (characteristic of sporadic desmoid tumors) in a large cohort of spindle cell lesions. None of the 175 spindle cell lesions, including low-grade sarcoma (low-grade fibromyxoid sarcoma and low-grade 
Table 4 Characteristics of desmoid tumors by CTNNB1 genotype

\begin{tabular}{|c|c|c|c|c|c|}
\hline CTNNB1 characteristics & $41 A(\%)$ & $45 F(\%)$ & $45 P(\%)$ & Deletion in exon $3(\%)$ & $\mathrm{P}$-value* \\
\hline$N$ & $132(59)$ & 49 (22) & 27 (12) & $9(4)$ & \\
\hline Age & & & & & 0.1192 \\
\hline Median, years & 41 & 37 & 40 & 58 & \\
\hline Range & $10-88$ & $1-80$ & $7-80$ & $39-71$ & \\
\hline Sex & & & & & 0.7329 \\
\hline Male & $36(56)$ & $15(23)$ & $10(16)$ & $3(5)$ & \\
\hline Female & $96(63)$ & $34(22)$ & $17(11)$ & $6(4)$ & \\
\hline Tumor site & & & & & 0.0023 \\
\hline Abdominal cavity & $41(78)$ & $6(11)$ & $5(9)$ & $1(2)$ & \\
\hline Abdominal wall & $32(63)$ & $6(12)$ & $11(22)$ & $2(3)$ & \\
\hline Extra-abdominal & $55(51)$ & $36(34)$ & $11(10)$ & $5(5)$ & 0.005 \\
\hline Head and neck & $7(54)$ & $4(31)$ & $2(15)$ & 0 & \\
\hline Trunk & $23(59)$ & $9(23)$ & $4(10)$ & $3(8)$ & \\
\hline Extremities & $25(45)$ & $23(42)$ & $5(9)$ & $2(4)$ & \\
\hline Unknown & 4 & 1 & 0 & 1 & \\
\hline Tumor size & & & & & 0.9425 \\
\hline Median, mm & 45 & 51,5 & 40 & 45 & \\
\hline Range & $5-200$ & 10-130 & $8-260$ & 10-100 & \\
\hline Unknown & 54 & 21 & 14 & 4 & \\
\hline Sample & & & & & 0.1292 \\
\hline Core needle biopsy & $27(49)$ & $18(33)$ & $7(13)$ & $3(5)$ & \\
\hline Chirurgical biopsy and surgical excision & $105(65)$ & 31 (19) & $20(12)$ & $6(4)$ & \\
\hline
\end{tabular}

41A, 45F, 45P, mutated residues; $n$, number of patients.

${ }^{*} P$-value: differences were considered statistically significant when $P<0.05$. Significant $P$-value is shown in bold.

Table 5 CTNNB1 mutations reported in previous studies in epithelial neoplasms

\begin{tabular}{|c|c|c|c|}
\hline Article & Tumor type & $\begin{array}{l}\text { Number of exon } 3 \\
\text { CTNNB1 mutations/ } \\
\text { number of the cohort }\end{array}$ & $\begin{array}{c}\text { Codon mutated (number of } \\
\text { cases) }\end{array}$ \\
\hline Garcia-Rostan et al ${ }^{18}$ & Anaplastic thyroid carcinoma & $19 / 31$ & $\begin{array}{c}17,20,22,33,36,37,38,40,41, \\
42,43,44,45,46,47,49,52,54, \\
55,58,60\end{array}$ \\
\hline Oliva et $a l^{19}$ & $\begin{array}{l}\text { Endometrioid tumors of borderline } \\
\text { malignancy of the ovary }\end{array}$ & $7 / 8$ & $32(2), 33(3), 37(2)$ \\
\hline Palacios et $a l^{20}$ & $\begin{array}{l}\text { Endometrioid ovarian borderline tumor } \\
\text { and carcinomas }\end{array}$ & $3 / 11$ & $37(2), 41 \mathrm{~A}(1)$ \\
\hline Voeller et $a l^{21}$ & Prostate carcinoma & $5 / 104$ & 31(1), 33(2), 41A(1), del 45(1), \\
\hline Koch et $a l^{22}$ & Hepatoblastoma & $27 / 52$ & $\begin{array}{c}\text { 32(2), 34(3), 37(1), 41A(7) large } \\
\operatorname{del}(14),\end{array}$ \\
\hline Miyoshi et $a l^{23}$ & Hepatocellular carcinomas & $14 / 75$ & $\begin{array}{l}\text { 32(5), 33(1), 34(1), 41A(1), } \\
\mathbf{4 5 F ( 2 ) , ~ 4 5 P ( 2 ) , ~ l a r g e ~ d e l ( 2 ) ~}\end{array}$ \\
\hline Fukuchi et $a l^{24}$ & Uterine endometrium adenoarcinoma & $10 / 76$ & $\begin{array}{c}\text { 33(1), } 37(2), 41 \mathrm{~A}(2), 41 \mathrm{I}(2), \\
45 \mathrm{C}(1), 45 \mathrm{~F}(2)\end{array}$ \\
\hline Mirabelli-Primdahl et $a l^{25}$ & $\begin{array}{l}\text { Colorectal carcinomas with high- } \\
\text { frequency MSI }\end{array}$ & $13 / 53$ & $\begin{array}{c}\text { 41A(3), 41I(2), } \mathbf{4 5 P ( 4 ) ,} \mathbf{4 5 F}(3) \\
\text { large } \operatorname{del}(1)\end{array}$ \\
\hline Mirabelli-Primdahl et $a l^{25}$ & $\begin{array}{l}\text { Colorectal carcinomas with stable or } \\
\text { low-frequency MSI }\end{array}$ & $0 / 27$ & \\
\hline
\end{tabular}

Abbreviations: del, deletion; MSI, microsatellite instability.

Exon 3 CTNNB1 point mutations identical to desmoid tumor is shown in bold.

sarcoma not otherwise specified), GIST, sarcomatoid carcinoma, malignant peripheral nerve sheath tumor, synovial sarcomas, benign proliferations (myofibroma, perineurioma, fibrothecoma, fibroma, lipofibromatosis and fibroblastoma) and reactive processes (nodular fasciitis, myositis and scar), harbored exon 3 CTNNB1 mutations. Recently, using a small cohort, Colombo et $a 1^{26}$ suggested that CTNNB1 genotyping can be useful in lesions where the differential diagnosis includes desmoid tumors, particularly in cases of suspected recurrence. Previously, Amary et $a l^{9}$ failed to detect the common 
Table 6 CTNNB1 mutations reported in previous sarcoma studies

\begin{tabular}{|c|c|c|c|}
\hline Article & Tumor type & $\begin{array}{c}\text { Number of exon } 3 \\
\text { CTNNB1 mutations/N of } \\
\text { cohort }\end{array}$ & $\begin{array}{l}\text { Codon mutated } \\
\text { (number of cases) }\end{array}$ \\
\hline \multirow[t]{3}{*}{ Iwao et $a l^{27}$} & Soft-tissue tumors & $2 / 62$ & \\
\hline & $\begin{array}{l}\text { MFH, osteosarcoma, synovial sarcoma, } \\
\text { liposarcoma, malignant schwannoma }\end{array}$ & $2 / 51$ & $\begin{array}{l}\text { SS: codon 32(1) MFH: } \\
\text { codon } \mathbf{4 5 P ( 1 )}\end{array}$ \\
\hline & Benign tumors & $0 / 11$ & \\
\hline Kuhnen et $a l^{28}$ & Pleomorphic-type MFH & $1 / 22$ & MFH: codon 37(1) \\
\hline Saito et $a l^{29}$ & Synovial sarcoma & $4 / 49$ & $\begin{array}{l}\text { Codon } 32(3) \\
\text { Codon } 37(1)\end{array}$ \\
\hline Sato et $a l^{8}$ & Synovial sarcoma & $0 / 15$ & \\
\hline \multirow{5}{*}{ Sakamoto et al ${ }^{24}$} & Liposarcoma and MFH & $6 / 39$ & \\
\hline & WDLS ‘lipoma-like’ & $0 / 10$ & \\
\hline & WDLS 'sclerosing' & $0 / 8$ & \\
\hline & DDLS & $2 / 12$ & $\begin{array}{l}\text { Codon 37(1) } \\
\text { Codon 39(1) }\end{array}$ \\
\hline & $\mathrm{MFH}$ & $4 / 9$ & $\begin{array}{l}\text { Codon 40(1) } \\
\text { Codon 42(1) } \\
\text { Codon 43(1) } \\
\text { Codon } \mathbf{4 5 P ( 1 )}\end{array}$ \\
\hline \multirow[t]{5}{*}{ Saito et $a l^{32}$} & Soft tissue sarcomas & $0 / 27$ & \\
\hline & MFH & $0 / 10$ & \\
\hline & LMS & $0 / 10$ & \\
\hline & MPNST & $0 / 5$ & \\
\hline & SFT & $0 / 2$ & \\
\hline
\end{tabular}

Abbreviations: DDLS, dedifferentiated liposarcoma; MFH, malignant fibrous histiocytoma; MPNST, malignant peripheral nerve sheath tumor; LMS, leiomyosarcoma; SFT, solitary fibrous tumor; SS, synovial sarcoma; WDLS, well-differentiated liposarcoma lipoma-like.

Exon 3 CTNNB1 point mutations identical to desmoid tumor is shown in bold.

CTNNB1 mutations in 57 spindle cell lesions but this cohort contained mainly cases of superficial fibromatosis. However, it should be noted that the 10 cases of low-grade fibromyxoid sarcoma did not present exon 3 CTNNB1 mutations, as was observed in our study. In addition, some studies have reported CTNNB1 mutations in various sarcomas. The various published studies looking for CTNNB1 mutations in soft tissue sarcomas are summarized in Table $6 .^{8,27-32}$ These studies showed that the prevalence of exon 3 CTNNB1 mutations in soft tissue sarcomas is very low. Rare cases of exon 3 CTNNB1 mutations were reported in synovial sarcoma and malignant fibrous histiocytoma. In most of these cases, this point mutation is situated in different codons $(32,37,39,40,42,43)$ from those generally observed in desmoid tumors (41 and 45). A mutation typical of a desmoid tumor (p.Ser45Phe) was observed in only two sarcoma cases (malignant fibrous histiocytoma). However, the high-grade atypia of malignant fibrous histiocytoma excludes them from the differential diagnosis of desmoid tumors.

When making a morphological diagnosis of a desmoid tumor in an intra-abdominal situation, searching for exon 3 CTNNB1 mutations (characteristic of sporadic desmoid tumors) turns out to be essential for the diagnostic approach. The presence of typical exon 3 CTNNB1 mutations allows us to make the diagnosis of sporadic desmoid tumors. On the other hand, the absence of exon 3 CTNNB1 mutations in this intra-abdominal location should suggest a family type of desmoid tumor and could help to select patients for whom $A P C$ gene mutations should be tested (Gardner's syndrome).

By comparing sequencing results from the formalin-fixed paraffin-embedded tissue samples paired to the frozen tumor specimens in a small cohort, Domont et $a 1^{15}$ have previously shown the feasibility of $\beta$-catenin gene sequencing using formalin-fixed paraffin-embedded tissues. In this study, we demonstrate in a large series that the use of formalin-fixed paraffin-embedded tissue samples is completely relevant and useful in daily routine practice. Furthermore, we show the feasibility of performing these analyses on core needle biopsies in the daily practice. Indeed, approximately one-third of our cases corresponded to such micro biopsies $(n=150,34 \%)$. In the field of sarcoma care, the current gold standard is based on the use of core needle biopsy.

CTNNB1 sequencing is easy to conduct and reproducible using formalin-fixed paraffin-embedded tissue obtained via core needle biopsy. Our study shows that sequencing of CTNNB1 exon 3 mutations is a specific diagnosis tool/test, which can resolve difficult situations in daily practice such as distinguishing desmoid tumors from benign or malignant fibroblastic lesions (eg, low-grade fibromyxoid sarcoma, GIST, leiomyosarcoma, sarcomatoid carcinoma, synovial sarcoma, nodular fasciitis, scar and other reactive processes). This finding is particularly useful to resolve cases where the histological interpretation of tumor samples resulting from core needle biopsies is complicated. Differentiating these three categories of lesions 
(desmoid tumor, sarcoma/carcinoma and reactive processes) becomes particularly important given the locally aggressive but non-metastasizing nature of deep fibromatosis, and the recent 'wait and see' approach for the management of desmoid tumor. ${ }^{6}$

\section{Acknowledgement}

We thank Pippa McKelvie-Sebileau of Institut Bergonié for medical editorial services.

\section{Disclosure/conflict of interest}

The authors declare no conflict of interest.

\section{References}

1 Reitamo JJ, Hayry P, Nykyri E, et al. The desmoid tumor. I. Incidence, sex-, age- and anatomical distribution in the Finnish population. Am J Clin Pathol 1982; 77:665-673.

2 Weiss RJ, Treiber M, Zahlten-Hinguranage A, et al. [Improving local control in patients with aggressive fibromatosis by combined surgery and radiotherapy]. Chirurg 2002;73:615-621.

3 Clark SK, Phillips RK. Desmoids in familial adenomatous polyposis. Br J Surg 1996;83:1494-1504.

4 Mendenhall WM, Zlotecki RA, Morris CG, et al. Aggressive fibromatosis. Am J Clin Oncol 2005;28: 211-215.

5 Melis M, Zager JS, Sondak VK. Multimodality management of desmoid tumors: how important is a negative surgical margin? J Surg Oncol 2008;98:594-602.

6 Fiore M, Rimareix F, Mariani L, et al. Desmoid-type fibromatosis: a front-line conservative approach to select patients for surgical treatment. Ann Surg Oncol 2009;16:2587-2593.

7 Alman BA, Li C, Pajerski ME, et al. Increased betacatenin protein and somatic APC mutations in sporadic aggressive fibromatoses (desmoid tumors). Am J Pathol 1997;15:329-334.

8 Sato H, Hasegawa T, Kanai Y, et al. Expression of cadherins and their undercoat proteins (alpha-, beta-, and gamma-catenins and p120) and accumulation of beta-catenin with no gene mutations in synovial sarcoma. Virchows Arch 2001;438:23-30.

9 Amary MF, Pauwels P, Meulemans E, et al. Detection of beta-catenin mutations in paraffin-embedded sporadic desmoid-type fibromatosis by mutation-specific restriction enzyme digestion (MSRED): an ancillary diagnostic tool. Am J Surg Pathol 2007;3: 1299-1309.

10 Bhattacharya B, Dilworth HP, Iacobuzio-Donahue C, et al. Nuclear beta-catenin expression distinguishes deep fibromatosis from other benign and malignant fibroblastic and myofibroblastic lesions. Am J Surg Pathol 2005;29:653-659.

11 Carlson JW, Fletcher CD. Immunohistochemistry for beta-catenin in the differential diagnosis of spindle cell lesions: analysis of a series and review of the literature. Histopathology 2007;51:509-514.
12 Montgomery E, Folpe AL. The diagnostic value of betacatenin immunohistochemistry. Adv Anat Pathol 2005;12:350-356.

$13 \mathrm{Ng}$ TL, Gown AM, Barry TS, et al. Nuclear betacatenin in mesenchymal tumors. Mod Pathol 2005;18: 68-74.

14 Lazar AJ, Tuvin D, Hajibashi S, et al. Specific mutations in the beta-catenin gene (CTNNB1) correlate with local recurrence in sporadic desmoid tumors. Am J Pathol 2008;173:1518-1527.

15 Domont J, Salas S, Lacroix L, et al. High frequency of beta-catenin heterozygous mutations in extra-abdominal fibromatosis: a potential molecular tool for disease management. Br J Cancer 2010;102:1032-1036.

16 Tejpar S, Nollet F, Li C, et al. Predominance of betacatenin mutations and beta-catenin dysregulation in sporadic aggressive fibromatosis (desmoid tumor). Oncogene 1999;18:6615-6620.

17 Lacroix-Triki M, Geyer FC, Lambros MB, et al. betacatenin/Wnt signalling pathway in fibromatosis, metaplastic carcinomas and phyllodes tumours of the breast. Mod Pathol 2010;23:1438-1448.

18 Garcia-Rostan G, Tallini G, Herrero A, et al. Frequent mutation and nuclear localization of beta-catenin in anaplastic thyroid carcinoma. Cancer Res 1999;59: 1811-1815.

19 Oliva E, Sarrio D, Brachtel EF, et al. High frequency of beta-catenin mutations in borderline endometrioid tumours of the ovary. J Pathol 2006;208:708-713.

20 Palacios J, Gamallo C. Mutations in the beta-catenin gene (CTNNB1) in endometrioid ovarian carcinomas. Cancer Res 1998;58:1344-1347.

21 Voeller HJ, Truica CI, Gelmann EP. Beta-catenin mutations in human prostate cancer. Cancer Res 1998; 58:2520-2523.

22 Koch A, Denkhaus D, Albrecht S, et al. Childhood hepatoblastomas frequently carry a mutated degradation targeting box of the beta-catenin gene. Cancer Res 1999;59:269-273.

23 Miyoshi Y, Iwao K, Nagasawa Y, et al. Activation of the beta-catenin gene in primary hepatocellular carcinomas by somatic alterations involving exon 3. Cancer Res 1998;58:2524-2527.

24 Fukuchi T, Sakamoto M, Tsuda H, et al. Beta-catenin mutation in carcinoma of the uterine endometrium. Cancer Res 1998;58:3526-3528.

25 Mirabelli-Primdahl L, Gryfe R, Kim H, et al. Betacatenin mutations are specific for colorectal carcinomas with microsatellite instability but occur in endometrial carcinomas irrespective of mutator pathway. Cancer Res 1999;59:3346-3351.

26 Colombo C, Bolshakov S, Hajibashi S, et al. 'Difficult to diagnose' desmoid tumours: a potential role for CTNNB1 mutational analysis. Histopathology 2011;59: 336-340.

27 Iwao K, Miyoshi Y, Nawa G, et al. Frequent betacatenin abnormalities in bone and soft-tissue tumors. Jpn J Cancer Res 1999;90:205-209.

28 Kuhnen C, Herter P, Muller O, et al. Beta-catenin in soft tissue sarcomas: expression is related to proliferative activity in high-grade sarcomas. Mod Pathol 2000;13:1005-1013.

29 Saito T, Oda Y, Sakamoto A, et al. Prognostic value of the preserved expression of the E-cadherin and catenin families of adhesion molecules and of beta-catenin mutations in synovial sarcoma. J Pathol 2000;192: 342-350. 
30 Saito T, Oda Y, Tanaka K, et al. beta-catenin nuclear expression correlates with cyclin D1 overexpression in sporadic desmoid tumours. J Pathol 2001;195:222-228.

31 Sakamoto A, Oda Y, Adachi T, et al. Beta-catenin accumulation and gene mutation in exon 3 in dedifferentiated liposarcoma and malignant fibrous histiocytoma. Arch Pathol Lab Med 2002;126: 1071-1078.

32 Saito T, Oda Y, Yamamoto $\mathrm{H}$, et al. Nuclear betacatenin correlates with cyclin D1 expression in spindle and pleomorphic sarcomas but not in synovial sarcoma. Hum Pathol 2006;37:689-697. 